\title{
The Pyrrhic Triumph of Finance Capital and the Return of Polanyi
}

\author{
By Trevor W. Harrison ${ }^{*}$
}

\begin{abstract}
This paper examines the declining support for centrist parties in many western countries. Using the seminal ideas of Karl Polanyi, the paper argues this decline is attributable to the rise of neo-liberal free market policies that have resulted in widespread insecurity and led many voters to seek out political alternatives on the right and left. The paper further examines possible reasons why parties of the right, rather than the left, have been more successful at this historical juncture in channeling political disenchantment.
\end{abstract}

\section{Introduction}

Underpinned by a set of economic and social policies broadly termed Keynesian, western governments after 1945 tacked their sails towards the centre of the political spectrum, with centre-left and centre-right parties taking turns at governing. Though these respective governments might disagree on particulars, they agreed on the basic tenets of economic and social policy. Just as importantly, they acted as brokerage parties in assuaging differences, and encouraging cohesion, among the variegated populations of their respective countries. Such was the nature of two party systems in the United States (the Democratic and Republican parties), Canada (the Liberals and Progressive Conservatives), and Great Britain (Labour and the Conservatives). But even in the major European countries where different electoral systems (e.g., proportional representation) allowed for a larger smorgasbord of parties and electoral coalitions, the principle of centrism adhered.

Beginning in the mid-1970s, however, support for the Keynesian welfare state (KWS) began to waver amidst rising inflation and escalating (and obdurate) unemployment, what came to be termed "stagflation." By the end of the decade, the principles of Keynesianism were openly dismissed in two major countries: in Great Britain, by the Conservative government of Margaret Thatcher (elected in 1979); and, in the United States, by the Reagan Republicans (elected the following year). Keynesianism was replaced as orthodoxy by an ideological formation known as neo-liberalism (sometimes, "neo-conservatism") whose major policy initiative has been the installation globally of free market capitalism. Coincident with the rise of neo-liberal globalization has been the erosion of support in many western countries for traditional, centrist parties, the emergence instead of new powerful political actors - often parties formerly viewed as extreme, especially on the right - and

*Professor, University of Lethbridge, Canada. 
a polarization of political debate and practice. Greece provides a particularly good example, with New Democracy on the centre-right and PASOK on the centre-left, today challenged on the extreme right by the neo-Nazis party, Golden Dawn, and on the left by Syriza.

Using the seminal ideas of Karl Polanyi, this paper argues that declining support for centrist parties (and politics) and the rise of neo-liberal globalization are inextricably linked. Specifically, it is argued that widespread insecurity brought about by neo-liberalism's assertion of self-regulating markets has resulted in a shift in citizen preferences away from traditional parties - who are often viewed as hand maidens to capital - in favour of (sometimes) radical alternatives. The paper ends with a discussion of possible reasons why parties of the right, rather than the left, have been more successful at this historical juncture in channeling political disenchantment.

\section{Polanyi's Thesis}

Karl Polanyi (1886-1964) was a Vienna-born political economist, historian, sociologist, and anthropologist. He was born and raised in what was then the Austro-Hungarian empire, witnessed its dissolution after the First World War, and later supported the social democratic government that arose briefly in Austria after 1918. During this time, he criticized the ideas of the influential Austrian School of Economics led by Ludwig von Mises and, later, Friedrich von Hayek who advocated laissez-faire economics. The Great Depression and the rise to power of Adolf Hitler in Germany saw Polanyi flee to London where he lived throughout most of the Second World War.

During this period, Polanyi wrote his major opus, The Great Transformation. The book was published in 1944, the same year that Hayek's The Road to Serfdom was also published. Two more polar opposite books have perhaps never been published in the same year. A brief discussion of Hayek's book highlights the quite different and original ideas put forward by Polanyi.

For Hayek, the state's role in economic planning spelled the end of individual liberty. The road to servitude was paved with good intentions, the alleviation of poverty and elimination of unemployment through state programs among them. Stalin's Russia was an extreme example, but Hayek and his followers believed Roosevelt's New Deal economics was on a slow track to the same outcome. The solution was laissez-faire economics, the unleashing of self-interest as Adam Smith and David Ricardo had written. In short, for Hayek, the free market was the guarantor of freedom and prosperity.

Polanyi took a very different view. The free market was not a guarantor of freedom, but rather an invitation to social and political breakdown.

Two concepts are particularly central to Polanyi's argument. The first is that of the embedded economy. Up until the 19th century, he argued, the economy had been "subordinated to politics, religion, and social relations" (Block, xxiv); that is, to society as a whole. Subsequent efforts to impose the laissez faire ideas of Smith and Ricardo upon society were doomed to failure: the 
economy could not be successfully dis-embedded. Nonetheless, the effort to do so had caused enormous political, social, and economic upheaval ever since.

This leads to Polanyi's second major concept, that of the "double movement." Efforts to impose unregulated markets led to enormous hardships in the form of social dislocation, unemployment, poverty - a veritable onslaught of creative destruction, as the economist Joseph Schumpeter (1994 [1942]) described - emphasis upon destruction - that intensified the faster and more widespread the changes were implemented. But as this first movement that of unregulated markets - proceeded, a second movement inevitably arose comprised of individuals, communities, and citizens protecting themselves from the economy's negative impacts. ${ }^{1}$

For Polanyi, the unraveling of society did not come about quickly or even simultaneously in all countries; nor was the type of double movements necessarily pre-ordained. The hundred year peace between the end of the Napoleonic wars and the outbreak of conflict in $1914^{2}$ hid a smoldering set of social and political conflicts whose varied solutions were later manifested in both Communism and Fascism, and other forms in-between. Thus was set in motion what Eric Hobsbawm (1994) described as one long war (1914 to 1945), a description with which Polanyi would have agreed, leading to a return to regulated markets.

\section{The Keynesian Welfare State and its Unravelling}

Neither Polanyi's nor Hayek's tomes immediately nor directly influenced post-war decision-makers. There was, however, widespread agreement that the Great Depression, with its enormous social and economic costs, had been a major factor in creating political instability; and that instability, in turn, had given rise to fascism, and hence to war. A dose of re-regulation was called for, embodied in Keynesian economics and welfare state reforms.

As an economic project, the Keynesian welfare state (KWS) sought to smooth out the business cycle with its inevitable crises of over-production and underconsumption. The mechanism was a set of counter-cyclical measures taken by the state - unemployment insurance, pensions, public assistance, expanded services, retraining, etc. - that would put money in the hands of people when the economy was in recession, thus maintaining demand, until such time as the economy rebounded and any deficits incurred could be drawn down through increased taxes as workers returned to employment and wages increased ${ }^{3}$

\footnotetext{
${ }^{1}$ The centrality that Polanyi places upon economic factors in destabilizing social and political formations appears at first glance reminiscent of Gramsci's concept of an "organic crisis." However, whereas, for Gramsci (and Marxist theorists generally) capitalism leads necessarily to an economic crisis, Polanyi appears to argue that it is the accelerated pace of change brought about by unregulated markets that is the central problem.

${ }^{2}$ In her critique of Polanyi, Halperin (2004) argues that his description of a hundred year peace seriously ignores the many conflicts that occurred outside of Europe and that social and political unrest occurred more often in non-liberal states.

${ }^{3}$ The type of welfare state and mix of programs varied greatly across western countries (see Olsen, 2002).
} 
As a political and social project, the postwar KWS involved a compromise between capital and labour, thus ending - at least temporarily - the historic war between workers and capitalists that Marxists had long viewed as the source of (inevitable) revolution. Labour accepted the right of capital to make a profit and to make decisions regarding company matters. In return, capital (that is, owners and managers) accepted labour's right to organize and bargain. Again, the state provided the legal, political, and often financial underpinning this compromise, though its interests remained in the end primarily tied to capital.

The KWS survived for twenty-five years. Its demise, beginning in the mid1970s, was immediately precipitated by the OPEC crisis of 1973. Rising oil prices destabilized (especially) the European industrial states, leading to inflationary pressures even as unemployment soared; thus was born a specific problem that Keynesian economics had not anticipated and for which it had no easy solution.

In the broader sense, however, the KWS was reliant upon two factors that by the 1970s no longer adhered: first, a relatively self-contained economy or at least one in which the state - hence also self-contained politics - could capture sufficient surplus for redistribution; and second, a high and sustained level of production. The first of these factors was challenged from the start by the inherently international nature of finance capital and its resistance to regulation. ${ }^{1}$ The second factor was a natural decline in productivity after the post-war catch up period. As Piketty (2014) has recently argued, the post-war prosperity that underpinned the welfare state was in fact an abnormal circumstance that, by the mid-1970s, simply ran out of steam.

The end of the KWS model led to a search for alternative models of capitalist development and governance. The result of this search was a rediscovery or, more accurately, a re-interpretation in some quarters of the ideas of Smith and Ricardo augmented by those of Hayek and his American disciple, Milton Friedman.

\section{The Three Periods of Neo-liberal Globalization}

The era of neo-liberal globalization can be divided into three relatively distinct periods: (1) ascendancy (the late 1970s and 1980s), (2) triumph (the 1990s), and (3) crisis (the 2000s and after) (Harrison and Friesen, 2011: 228230).

The ascendancy period began with the crisis of Keynesianism in the 1970s, followed by the elections of British Prime Minister Margaret Thatcher in 1979 and American President Ronald Reagan in 1980. In the early stages, states were internally disciplined to the requirements of the market: public services were privatized or reduced, finance capital deregulated, corporate taxes lowered, and the power of unions curtailed. In the later stages, neo-liberal policies were exported, beginning with the signing of the Canada-U.S. Free

${ }^{1}$ I have elsewhere written about the growth in size and importance of finance capital relative to other forms of capital during this period (see Harrison, forthcoming). 
Trade Agreement in 1989 and its subsequent extension to Mexico and, finally, other states and regions. The new era of globalization seemed at first irresistible, drawing in politicians, governments, businesses, and academics. Takeovers and mergers; stock options and buyouts; above, all the notion of markets über alles, became the mantra.

The beginning of the triumphal period witnessed the symbolic collapse of the Soviet Union in 1991, heralded by President George H.W. Bush's declaration of a "New World Order." During this period, the United States emerged as the "uni-polar" centre of world power, promoting a set of neoliberal policies otherwise termed the "Washington Consensus." The NAFTA agreement signed in 1993 signaled further efforts to liberalize trade. Within a short time, however, the neo-liberal project ran into difficulties.

The first of these difficulties was primarily economic. Almost immediately, financial instability ensued, beginning with a serious market downturn in 1987, resulting from the collapse of tech stocks; followed by a recession in the early 1990s; and then a worldwide banking crisis of 1997.

The beginning of the 2000s saw neo-liberalism enter its crisis stage from which it has not yet fully recovered. The period began with another recession that intensified after the terrorist attacks on New York and Washington in September 2001. Even before this time, however, the economic crises took on a political dimension as neo-liberal globalization began creating its own antagonists. The late 1990s witnessed the rise of anti-globalization movements throughout much of the western world, fostered ironically by the same computer technologies that had fostered global capitalist expansion. Mass protests took place in Washington, D.C., Quebec City, Genoa, and other cities, spurred by opposition to globalization's impacts (e.g., environmental damage, global warming, and rising inequality). The War on Terror after 9/11 dampened but did not end the impetus to double-movement activity, which burst alight again with the start of the Great Recession in 2007.

The Great Recession was the gravest crisis of capitalism since the Great Depression. As in 1929, the crisis led to a drying up of bank credit followed by a surge in lay-offs. The world economy came to a screeching halt and was revived only when the major economies injected $\$ 20$ trillion into the system (McNally, 2010). The crisis did not end with the economy, however, but quickly moved into society as layoffs continued and - in the United States particularly - foreclosures accelerated and the price of housing stock declined. Ultimately, the crisis caused a loss of faith in markets, political institutions, and the political class itself; at its height, the arch-conservative French President Nicolas Szarkozy declared the end of laissez-faire capitalism, though his deathbed conversion did not save his government in the election that followed. In Great Britain, the Labour party went down to defeat at the hands of the Tory party. In the United States, the Republicans lost the presidency to the Democrats. In Hungary and Greece, neo-fascist parties gained in support, though the latter also saw both breakup and renewal on the left. 
Underlying this political discord has been a growing gap between the world's super rich and the poor, with the middle class in many western countries under threat (see Piketty, 2014). An Oxfam report in late 2013 stated that the wealthiest 85 people in the world now possess as much wealth as the bottom 50 percent of humanity. The majority of this wealth is a product of finance capital. As incomes, wealth, and opportunity have declined in many countries, old ethnic, racial, and regional cleavages and conflicts have reemerged. As the poet Yeats wrote, "the centre does not hold."

Of course, one should not entirely dismiss the power of centrist parties. They continue to hold real power in many countries. Combined with inertia and a psychological regression to the mean among voters, centrist parties may continue to govern. But threats to their authority - and to social cohesion - are real, fed by a belief among many citizens that centrist parties are either passively ineffectual or actively culpable for the recent collapse and for the more long-term problems of economic decline experienced in western countries. In consequence, there have arisen on either side of the political spectrum - as Polanyi would have predicted - double movements seeking to protect their communities (however defined). The Tea Party movement and the Occupy movement are an expression, in the United States, of this diversity, yet springing from the same fears and anxieties.

At the same time, one is forced to admit that, in the main, such expressions have been more successful on the right - even the extreme right - than on the left in mobilizing discontent; the recent European parliamentary elections provide an example, with the National Front in France and Golden Dawn in Greece continuing to rise in support. Why is this the case?

\section{Stagnant Left, Rising Right}

To understand the left's dilemma, one must go back to the left's formative debates between nationalists vs. internationalists and revolutionaries vs. reformers, the latter about whom Marx wrote scathingly in The Communist Manifesto. The revolutionaries believed that capitalism could not be tamed and had to be defeated through active class struggle; they further believed that communism could not exist in any country unless it existed in every country. The reformers, by contrast, argued that capitalism could be brought to heel through the democratic process - evolution rather than revolution; and, further, that a kind of détente could be reached with capital.

The revolutionary (Marxist-Leninist) model collapsed in the early 1990s; thus died "real communism." The reformist (social democratic) model has survived better, especially in the Scandinavian countries, but not without often surrendering much of its platform and ideals in the name of political expediency or fears of capitalist retaliation; far from taming capitalism, capitalism has instead tamed socialism, leaving erstwhile social democratic parties appearing little different from their liberal counterparts. The British Labour party under Tony Blair provides a particularly stark example, as it often 
built on the legacy of Margaret Thatcher in privatizing and deregulating services, lowering taxes, assaulting labour rights, and (in the case of the Iraq War) tying itself to American imperial aims. But there are other more recent and less extreme examples, such as Greece, where PASOK remains a socialist party in name only, dedicated more to its own political survival than to advancing anti-capitalist principles; or France, where Francois Hollande's government, elected in 2012 on an anti-austerity platform, has since moderated its policies in order to quell the concerns of capital markets.

More generally, however, the failure of double-movements on the left to gain political traction during the recent crises of laissez-faire capitalism can best be explained by: 1) the specter of real communism that still haunts much of the left's memory, blunts its will, and holds it back from action; 2) the cooptation and becalming of social democratic parties; they are now viewed, not incorrectly, as part of the established order; 3) a rejection by many (young) left supporters of formal politics and the notion of class struggle in favour of new social movements and identity politics; and 4) the decline of working class power resources (see Olsen, 2002) as a result of globalization's outsourcing of jobs.

By contrast, what explains the greater relative success of right-wing counter-movements? Again, four factors stand out: 1) the continued presence of ethnic-nationalist and nativist sentiments within much of the populations of Europe and North America. Even left parties in eastern Europe tend towards right-wing (traditional-authoritarian-nationalist) appeals (Bakker et al., 2010); 2) the promulgation of cultural beliefs supportive of capitalism's individualized and consumerist ethos which appeal to libertarian rather than communitarian values; 3) the failure of states to effectively deal with a plethora of escalating crises. In the words of Daniel Bell (1993: 362), the state often seems too big to deal with the small problems and too small to deal with the big problems; and 4) the real and tacit support given by capitalists to right-wing movements, of which the Koch brothers support of the Tea Party movement in the United States provides a good example (see Mayer, 2010; also, Dimaggio, 2011).

\section{Conclusion}

Today, centrist parties and governments throughout the western world find their support drifting away to new political parties, often on the extreme right. Using the seminal ideas of Karl Polanyi, this paper has argued that the political crisis facing centrist, or brokerage parties, is the result of neo-liberal economic globalization, specifically the idea of unregulated markets whose implementation has heightened feelings of insecurity among many citizens and communities and led them to seek out new political alternatives.

Will laissez-faire capitalism continue to dominate politics and society? When the recent crisis erupted, many politicians, pundits, and academics argued for a return to financial regulation and reinvestment in states and 
communities. There was renewed talk of a "Tobin tax" to slow down financial transactions.

But memories are short. Today, global markets have regained all they lost during the Great Recession, and talk has returned to mergers, takeovers, deregulation, privatization, and the signing of free trade deals, such as the Asia-Pacific Trade Agreement (APTA) or the Comprehensive Economic and Trade Agreement (CETA); in short, the continued freeing up of capital. No one seriously talks any longer of capitalism in crisis. The cancer of financial collapse having vanished, talk also of controlling capital has also gone into remission.

But, if the past thirty years are any predictor, another crisis must soon be at hand, and with it the return of political instability of which Karl Polanyi warned some seventy years passed.

\section{References}

Bakker, Ryan, Seth Jolly, and Jon Polk, and Jan Rovny. 2010. The Dimensionality of Party Politics in Europe. Draft. Paper presented at the European Consortium for Political Research's Fifth Pan-European Conference on EU Politics, Porto, Portugal, June 23-26.

Bell, Daniel. 1993. "The third technological revolution: And its possible socioeconomic consequences." In K. Finsterbusch and J. Schwartz (eds.), Sources: Notable Selections in Sociology, 351-365. Guilford: Dushkin.

Block, Fred L. The Origins of International Economic Disorder. Berkeley: University of California Press, 1977.

Dimaggio, Anthony. 2011. The Rise of the Tea Party. Political Discontent and Corporate Media in the Age of Obama. New York: Monthly Review Press.

Gramsci, Antonio. 1988. "Prison writings." In D. Forgacs (ed.), An Antonio Gramsci reader: Selected Writings, 1916-1935. New York: Schocken Books.

Halperin, Sandra. 2004. War and Social Change in Modern Europe. The Great Transformation Revisited. Cambridge University Press.

Harrison, Trevor. Forthcoming. "A Tale of Two (Global) Cities: London, New York, and the Rise of Finance Capital." In G. Anderson and C. Kukucha (eds.), International Political Economy (draft title). New York: Oxford.

Harrison, Trevor, and John Friesen. 2011. Canadian Society in the $21^{\text {st }}$ Century. An Historical Sociological Approach. Second Edition. Toronto: CSPI.

Hayek, Friedrich von. 1994. The Road to Serfdom. Originally published 1944. Chicago: University of Chicago Press.

Hobsbawm, Eric. 1994. Age of Extremes: The Short Twentieth Century 1914-1991. London: Abacus.

Mayer, Jane. 2010. "The billionaire brothers who are waging a war against Obama." The New Yorker, August 30.

McNally, David. Global Slump: The Economics and Politics of Crisis and Resistance. Oakland, California: PM Press, 2010.

Olsen, Gregg. 2002. The Politics of the Welfare State: Canada, Sweden, and the United States. Oxford: Oxford University Press.

Piketty, Thomas. 2014. Capital in the Twenty-First Century. A. Goldhammer (tr.). Cambridge, Mass.: Belknap. 
Polanyi, Karl. The Great Transformation: The Political and Economic Origins of Our Time. Originally published 1944. Boston: Beacon Press, 2001.

Schumpeter, Joseph. 1994. Capitalism, Socialism, and Democracy. Originally published in 1942. London: Routledge. 
